\title{
Uncovering Gender Differences in Saudi EFL Learners' Attitudes Towards the Use of Instagram as a Language Learning Tool
}

\author{
Lima A Alzamil \\ Department of English Language and Translation \\ College of Arabic Language and Social Studies, Qassim University \\ Qassim, Saudi Arabia \\ E-mail: limaalzamil@gmail.com
}

Received: August 3, 2020 Accepted: September 5, 2020 Published: September 20, 2020

doi:10.5296/ijl.v12i5.17486

URL: https://doi.org/10.5296/ijl.v12i5.17486

\begin{abstract}
The widespread popularity of social media networks has encouraged learners to use them for learning purposes. Therefore, this study aimed to investigate the overall Saudi EFL learners' attitudes towards the use of Instagram as a language learning tool. It also examined the effect of gender on learners' attitudes. The study was conducted among 120 male and female EFL learners at Qassim University using a questionnaire. The results revealed that subjects had relatively positive attitudes toward the use of Instagram as a language learning tool. The results also indicated that there are no significant differences between male and female EFL learners in terms of their attitudes towards the use of Instagram as a language learning tool. The study concluded with implications related to how Instagram should be used as a supportive tool in English language teaching and learning.
\end{abstract}

Keywords: Social media networking, EFL learners, Language learning, Instagram

\section{Introduction}

In the present century, online social websites are considered as one of the essential phenomena of technology due to the increasing number of users around the world (Aljaad, 2016). Internet and social media websites make people live in a global village as they enable users to browse different websites concurrently (Ta'amneh, 2018). Social software technologies have become an integral part of individuals' life as well as English language 
learners' life as they enable learners to be frequently exposed to language due to their effective use of social platforms for learning or communication purposes (Alsharidi, 2018). The everyday use of the internet has played an active role in the improvement of students' English language and has brought significant changes in the way students use information (AlQahtani, 2018). Therefore, on account of the increasing popularity of social network sites, educationists tend to use them as a learning tool since such social media platforms as Instagram, Facebook, Twitter are considered as a plentiful and renewable source for education.

Current trends in language learning and teaching encourage the integration of technology into the learning and teaching process (Gonulal, 2019). The field of education, in general, is undergoing rapid changes in terms of teaching approaches and methods that require adopting new technologies in and out of the classroom in view of the interests and needs of students and teachers (Aloraini, 2018). Sharma (2018) claims that "amalgamating social media into course specification, course objectives, and curriculum may seem a relatively new field but surely have a great potential to carve niches in students' EFL learning” (p. 138). Instagram is one of plenty of social media network sites that have been popular all around the world.

People use Instagram for different purposes; they may use it for entertainment, business, or even learning. Even though Instagram is not designed as an educational application, language learners use it actively in language learning (Gonulal, 2019). Erarslan (2019) claims that Instagram is a useful and motivating tool for fostering learning. Instagram provides learners with interesting content that includes short videos and attractive figures and photos.

\subsection{Context of the Problem}

It is the researcher's belief that Saudi English language learners need to find resources to improve and practice their knowledge and skills because they cannot practice their English language in everyday life as they live in an Arabic environment. The widespread acceptance and use of social media among people, including students, "have drawn attention to investigate the benefit and drawbacks of these modern technologies for educational purposes including English language learning" (Alqarni et al., 2018, p. 10662). The number of educators and learners who use these tools for communication and interaction is consistently increasing, which ensures the importance of employing social networks in learning English as an alternative to the traditional approaches (Chartrand, 2012). Therefore, social media networks can be an effective resource for learning English.

Instagram is one of these social media platforms that provide learners with engaging content that includes short videos and attractive figures and photos. Learners' background and beliefs about Instagram's effectiveness in learning determine their use of Instagram as a learning tool. Thus, learners' attitudes towards the use of Instagram as a language learning tool should be investigated.

A considerable amount of research has been undertaken to examine the role of social media networks in learning (Aljaad, 2017; AlQahtani, 2018; Vivakaran \& Neelamalar, 2018). Other investigations have explored students' attitudes and perspectives towards the use of social 
media networks in learning (Aifan, 2015; Alqarni et al., 2019; Bal \& Bicen, 2017; Beqiri, 2014; Sharma, 2019; Ta'amneh, 2018)

Although the literature is replete with studies regarding the use of such social media platforms as Facebook and Twitter for educational purposes (AbuSa'aleek, 2015; Alsharidi, 2018; Gamble \& Wilkins, 2014; Junco et al., 2010; Kaya \& Bicen, 2016; Razak et al., 2013), Instagram has not been studied in detail in terms of its use for educational purposes.

Some studies (Al-Ali, 2014; Erarslan, 2019; Gunolal, 2019; Shazali et al., 2019; Soviyah \& Etikaningsih, 2018) have suggested that Instagram could be utilized as a useful tool to improve learners' English language skills. However, few studies have investigated Instagram as a language learning tool. Additionally, very few studies have considered gender differences in students' attitudes towards the use of Instagram as a language learning tool. The present study, therefore, intends to examine the impact of students' gender on their attitudes towards the use of Instagram as a language learning tool.

\subsection{Problem of the Study}

As introduced above, there is a persistent need to investigate how Saudi EFL learners' attitudes towards the use of Instagram as a language learning tool differ according to their gender. This study will be an extension to what has been done in regard to social network sites as language learning tools (Aifan, 2015; Al-Ali, 2014; Aljaad, 2016; AlQahtani, 2018; Erarslan, 2019; Gunolal, 2019)

\subsection{Research Questions}

1- What are Saudi EFL learners' attitudes towards the use of Instagram as a language learning tool?

2- To what extent do gender differences affect Saudi EFL learners' attitudes towards the use of Instagram as a language learning tool?

\subsection{Hypothesis of the Study}

1- Saudi EFL learners have positive attitudes towards the use of Instagram as a language learning tool.

2- There are no significant effects of gender on Saudi EFL learners' attitudes towards the use of Instagram as a language learning tool.

\subsection{Significance of the Study}

This study is significant for both theoretical and practical reasons. Theoretically, this study is intended to give further information about learners' attitudes towards the use of Instagram as a language learning tool. It also extends the discussion about learners' attitudes by looking at the effect of gender on learners' attitudes towards the use of Instagram as a language learning tool. Practically, this study provides EFL instructors with guidelines to adopt Instagram as a supplementary teaching tool in and out of the classroom. 


\subsection{Review of Literature}

\subsubsection{Theoretical Background}

The theoretical formulation of the relationship between technology and learning as a cooperative and collaborative process is usually in terms of constructivism, social learning theory, cooperative learning theory, and, more recently, collaboration theory (Hmelo-Silver, 2006). According to Vygotsky's (1978) social constructivist theory, education is not merely a cognitive process, but it is also a socio-cultural theory that requires social interaction between learners. Jacobs et al. (2002) defined cooperative learning as "principles and techniques for helping students work together more effectively" (p. 1). Social learning theory associates learning with behavior, and "emphasizes the continuous reciprocal interaction between the factors of individuals' behavior (cognitive) and environmental influences in understanding social cognitive learning process" (Harinie et al., 2017, p. 1). These theories can have beneficial implications in learning as social media network sites can help learners practice and improve their English language in a collaborative and interactive community.

\subsubsection{Related Studies}

\subsubsection{Social Media}

Many studies have been conducted to investigate the use of social media platforms in language learning. Vivakaran and Neelamalar (2018) surveyed faculty members in higher educational institutions in urban and technologically deprived rural areas to examine the role of social media websites as teaching aids in higher education. They reported that only a few faculty members were found to be experimenting with social media as a pedagogical tool in their classes. The researchers also indicated that students affected faculty members' motivation to use social media tools in their classrooms.

As regards students' beliefs and perspectives, Bal and Bicen (2017) conducted a quantitative study using a questionnaire to determine the purpose of Turkish students' use of social media and to explore their perspectives on the use of social media in education. The study revealed that social media enables students to acquire new information and provides them with integrative learning that contributes to their lesson achievements through online study groups, which provides them with an active environment that enhances their motivation. Additionally, using a structured questionnaire, Beqiri (2014) explored the current usage of social media and the impact of social media in higher education from students' perspectives. The findings of Beqiri's study indicated that social media has a positive impact on students in terms of study-related activities and on students' communication.

Yang and Tang (2003) conducted a Web-based forum study to explore how social networks affect students' performance in online education. They found that advising network variables affected students' performance positively, while adversarial variables affected students' performance negatively.

In the Saudi context, Ta'amneh (2018) investigated Saudi learners' attitudes towards the effect of social media in developing their English language. He found that Saudi learners have 
positive attitudes towards the use of social media in developing their English language. In addition, Aifan (2015) investigated the factors and barriers affecting Saudi students' attitudes towards using social media. She found that students' attitudes towards using social media for learning are affected by five factors, which are perceived ease of use, perceived usefulness, subjective norms, experience with Skype, and age. Concerning the berries that prevent students from using social media, students reported that some social media contents oppose their religious beliefs, and their concerns about privacy and security issues limit their use of social media.

\subsubsection{Twitter}

Many studies have investigated the use of different social media platforms for educational purposes. Twitter is a social media platform that has been popular all around the world. Therefore, some researchers have studied Twitter as a language learning tool. Using a mixed-method approach, Alsharidi (2018) explored Saudi female EFL learners' perceptions of Twitter as a tool for practicing English. The findings revealed that learners' use of English in their communication was purposed for social purposes rather than educational purposes. In addition, she found that students' use of Twitter to practice English enables them to be engaged in real English contexts, which helps them develop their language easily.

Some other studies have been conducted to examine the effectiveness of Twitter in teaching particular language skills. Mompean and Fouz-Gonzalez (2016) carried out a study using a Twitter-based program with students from a language school in Spain to examine the effectiveness of using Twitter in teaching pronunciation. The results showed that Twitter was an effective tool for teaching pronunciation. As regards writing, Taskiran et al. (2016) employed an explanatory sequential mixed methods design to examine the effectiveness of Twitter in practicing creative writing outside the classroom. The findings revealed that Twitter was a supporting platform that reinforces writing activities outside the classroom.

Junco et al. (2010) carried on an experimental study to investigate the impact of using Twitter for educationally relevant purposes on students' engagement. The researchers found that the use of twitter increased students' engagement.

\subsubsection{Facebook}

Gamble and Wilkins (2014) surveyed Japanese students to investigate their attitudes and perceptions towards the usefulness of Facebook in participating in language learning activities. The findings showed that students' perspectives towards the ease of using Facebook for educational purposes were positive. Moreover, the results indicated that students' attitudes towards the usefulness of Facebook in participating in specific language learning activities were generally positive. Similarly, in the Saudi context, AbuSa'aleek (2015) undertook a quantitative study to investigate students' affective domains. The findings indicated that Facebook facilitates and supports language learning, and Facebook enhances students' motivation and confidence in English language learning.

In regard to language skills, some researchers carried out some studies to investigate the effectiveness of using Facebook in learning particular language learning skills. For example, 
to examine the effectiveness of Social Networking Sites (SNSs) as online communities of practice, Razak et al. (2013) adopted Facebook as an interactive and collaborative community for practicing writing. They found that Facebook, as an interactive learning environment, enhanced learners' writing and engagement with their instructors and peers.

\subsubsection{Instagram}

Few studies have been conducted to investigate the effectiveness of Instagram as a language learning tool. Both Aloraini (2018) and Gunolal (2019) undertook their studies among Instagram users who use it for English language learning to investigate Instagram as a language learning tool. Aloraini's (2018) findings indicated that vocabulary posts encouraged commenters to give more output. She also indicated that the type of posts does not affect learners' output quality and does not raise the amount of feedback provided for learners. Gunolal (2019) reported that learners have positive attitudes towards the use of Instagram for language learning.

Erarslan (2019) conducted a mixed-method study to explore students' opinions about the use of Instagram for educational purposes and its impact on students' language learning. The findings showed that students favor using Instagram for language learning, and indicated that using Instagram has a positive impact on students' language learning based on the scores derived from the experimental part.

In respect to the use of Instagram for specific language skills, Soviyah and Etikaningsih (2018) investigated the effectiveness of the use of Instagram on students' performance in writing descriptive texts by comparing two groups of students, one of them was taught using Instagram pictures, while the other was taught without using Instagram pictures. He reported that using Instagram pictures had a positive effect on students' performance in writing descriptive texts. Similarly, Handayani et al. (2018) conducted a pre-experimental study to examine the effectiveness of Instagram in improving students' ability to write opinion essays and investigated students' perceptions of the use of Instagram as a language learning tool. They indicated that Instagram was effective in improving the quality of students' essays. They also indicated that students viewed Instagram as an effective and enjoyable educational tool to be used in the class. However, the previous studies show that gender differences in students' attitudes towards the use of Instagram as a language learning tool have not received considerable consideration. Therefore, the current paper attempts to address this gap.

\section{Method}

\subsection{Subjects}

Saudi EFL undergraduates who were enrolled in the department of English and Translation at Qassim University were invented to respond to a questionnaire. Sixty males and sixty females completed the questionnaire. The subjects were selected because they have practical and relevant experience in English language learning. The subjects were native speakers of Arabic, and they were from different levels as the use of Instagram as a language learning tool applies to different levels of learning. 


\subsection{Instrument}

The questionnaire was used as a primary instrument for this study. The questionnaire items were adopted from Gunolal's (2019) Six-Likert scale questionnaire, and they were not changed. The present study modified the design of Gunolal's (2019) questionnaire to be based on a five-point Likert scale to make it easier for the subjects to respond to it. The questionnaire consists of 15 closed-ended questions written in English, as the subjects were EFL learners. Reliability Cronbach's Alpha Coefficient was used to assess the level of reliability of the questionnaire. Cronbach's alpha level was 0.91, which indicates a high consistency of reliability.

The questionnaire was designed using Google form and published via social media during the second semester of the academic year 2020. EFL learners at Qassim University were requested to complete it anonymously. In order to facilitate the analysis of data, the researcher used two forms of the questionnaire. One form was addressed to the males, and the other was addressed to females. The two questionnaires included the same questions.

\subsection{Data Analysis}

After collecting subjects' responses from the questionnaire, the data were analyzed statistically using SPSS 15.0 package program. Frequencies mean scores and standard deviations were used to analyze each item of the questionnaire. Following Gunolal's (2019) method, the researcher divided attitudes into positive and negative, although the Five-Likert Scale questionnaire was used. The researcher used a questionnaire based on a five-point Likert scale to make it easier for the subjects to respond to the questions. The differences between male and female learners were analyzed using a t-test for independent samples, and significant levels were set at $\mathrm{p}<0.05$.

\section{Results and Discussion}

This study aims to answer two questions. The first question dealt with overall Saudi EFL learners' attitudes towards the use of Instagram as a language learning tool. The second question focused on the impact of gender on the learners' attitudes towards the use of Instagram as a language learning tool. The results are presented and discussed according to the order of the research questions as follows:

\subsection{Analysis of Saudi EFL Learners' Attitudes Towards the Use of Instagram as a Language Learning Tool}

Table 1 provides descriptive statistics for the overall EFL learners' attitudes towards the use of Instagram as a language learning tool. The results were given as mean scores and standard deviations. 
Table 1. Saudi EFL learners' attitudes towards the use of Instagram as a language learning tool

\begin{tabular}{lll}
\hline Statements & M & SD \\
\hline Instagram is suitable for educational purposes. & 3.16 & 1.092 \\
\hline Instagram is a good platform to practice writing in English. & 2.91 & 1.138 \\
\hline Instagram is a good platform to read in English. & 3.78 & 1.022 \\
\hline Instagram is a good platform to develop English communication skills. & 3.68 & 0.953 \\
\hline Instagram is a good platform to overcome language mistakes. & 3.03 & 1.069 \\
\hline Instagram is a good platform to learn new words in English. & 4.24 & 0.953 \\
\hline Instagram is a good platform to improve English grammar knowledge. & 2.95 & 1.144 \\
\hline Instagram is a good platform to improve overall English skills. & 3.44 & 0.915 \\
\hline Instagram is a good platform to reach authentic English materials. & 3.05 & 0.995 \\
\hline Instagram makes learning English more interesting. & 3.87 & 0.952 \\
\hline Instagram makes learning English easier. & 3.5 & 0.953 \\
\hline Instagram increases my motivation to communicate using English. & 3.77 & 1.035 \\
\hline Instagram increases my motivation to read English materials. & 3.67 & 0.982 \\
\hline Instagram increases my motivation to write in English. & 3.4 & 1.016 \\
\hline Instagram encourages me to spend more time learning English. & 3.35 & 1.001 \\
\hline
\end{tabular}

Overall, subjects had relatively positive attitudes towards the use of Instagram as a language learning tool ( $\mathrm{M}=3.16, \mathrm{SD}=1.092)$. Specifically, when looking at the educational purposes of using Instagram, subjects largely discerned that Instagram can be a good platform to learn new vocabulary $(\mathrm{M}=4.24, \mathrm{SD}=0.953)$. Learners can learn new vocabulary through Instagram due to its capability to combine texts with photos and videos, which helps learners be exposed to new words optimally. They also believed that Instagram could be a good platform to read in English $(\mathrm{M}=3.78, \mathrm{SD}=1.022)$ and develop English communication skills $(\mathrm{M}=3.68$, $\mathrm{SD}=0.953$ ). Instagram enables learners to interact and discuss ideas with native speakers, which promotes a wider sense of social community (Beqiri, 2014; Gunolal, 2019; Renaldi, 2020).

Further, subjects believed that Instagram makes learning English more interesting $(\mathrm{M}=3.87$, $\mathrm{SD}=0.952)$, increases learners' motivation to communicate using English $(\mathrm{M}=3.77$, $\mathrm{SD}=1.035)$, and increases learners' motivation to read English materials $(\mathrm{M}=3.67, \mathrm{SD}=0.982)$. Also, learners considered Instagram as a good platform to overcome language mistakes $(\mathrm{M}=3.03, \mathrm{SD}=1.069)$. This result is expected because Instagram includes many accounts that provide learners with videos that help them understand how to use language perfectly. Moreover, subjects had mostly positive attitudes towards the effectiveness of Instagram in enhancing their motivation to write in English $(\mathrm{M}=3.4, \mathrm{SD}=1.016)$. This can be attributed to the attractive visual content that Instagram provides, which can help them brainstorm new ideas and topics. Thus, this result is consistent with the study of Soviyah and Etikaningsih (2018), which indicated that "teaching students writing by using Instagram pictures is more effective than teaching without using Instagram pictures." (p. 32). 


\section{Mll Macrothink}

International Journal of Linguistics

ISSN 1948-5425

2020, Vol. 12, No. 5

On the other hand, subjects had slightly negative attitudes towards the effectiveness of Instagram in practicing writing $(M=2.91, S D=1.138)$. In the same vein, Akhiar et al. (2017) indicated that "students demonstrated mediocre attitudes towards using Instagram for English language writing" (p. 56). By contrast, Shazali et al. (2019) pointed out that students had positive attitudes towards the use of Instagram for writing. In addition, subjects had slightly negative attitudes towards the use of Instagram as a tool for improving English grammar knowledge $(\mathrm{M}=2.95, \mathrm{SD}=1.144)$. Gunolal (2019) attributed this to the informal language that Instagram users may use.

The findings revealed that Saudi EFL learners' attitudes towards the use of Instagram as a language learning tool were mostly positive. The results of this study tie well with previous studies, wherein Gunolal (2019) demonstrated that ELLs had positive attitudes towards the use of Instagram as a language learning tool. Consequently, the previous discussion verifies the validity of the first research hypothesis, "Saudi EFL learners have positive attitudes towards the use of Instagram as a language learning tool."

3.2 Analysis of Gender Effect on Learners' Attitudes Towards the Use of Instagram as a Language Learning Tool

Another aim of this study was to examine whether there are any significant differences between male and female EFL Saudi learners' attitudes towards the use of Instagram as a language learning tool in relation to the questionnaire items. Towards this end, an independent samples t-test was used to test the hypothesis that there are no significant effects of gender on Saudi learners' attitudes towards the use of Instagram as a language learning tool.

Table 2. Gender differences in Saudi EFL learners' attitudes towards the use of Instagram as a language learning tool

\begin{tabular}{|c|c|c|c|c|c|c|}
\hline Statements & Gender & $\mathrm{N}$ & M & SD & $\mathrm{df}$ & $\begin{array}{l}\text { Sig. } \\
\text { (2-tailed) }\end{array}$ \\
\hline \multirow{2}{*}{$\begin{array}{l}\text { Instagram is suitable for } \\
\text { educational purposes. }\end{array}$} & Male & 60 & 3.22 & 1.223 & \multirow{2}{*}{111.283} & \multirow{2}{*}{0.561} \\
\hline & Female & 60 & 3.10 & 0.951 & & \\
\hline \multirow{2}{*}{$\begin{array}{l}\text { Instagram is a good platform to } \\
\text { practice writing in English. }\end{array}$} & Male & 60 & 2.97 & 1.235 & \multirow{2}{*}{118} & \multirow{2}{*}{0.576} \\
\hline & Female & 60 & 2.85 & 1.039 & & \\
\hline \multirow{2}{*}{$\begin{array}{l}\text { Instagram is a good platform to } \\
\text { read in English. }\end{array}$} & Male & 60 & 3.68 & 1.097 & \multirow{2}{*}{118} & \multirow{2}{*}{0.286} \\
\hline & Female & 60 & 3.88 & 0.940 & & \\
\hline \multirow{2}{*}{$\begin{array}{l}\text { Instagram is a good platform to } \\
\text { develop } \quad \text { English } \\
\text { communication skills. }\end{array}$} & Male & 60 & 3.57 & 1.031 & \multirow[b]{2}{*}{118} & \multirow[b]{2}{*}{0.181} \\
\hline & Female & 60 & 3.80 & 0.860 & & \\
\hline \multirow{2}{*}{$\begin{array}{l}\text { Instagram is a good platform to } \\
\text { overcome language mistakes. }\end{array}$} & Male & 60 & 2.85 & 1.117 & \multirow{2}{*}{118} & \multirow{2}{*}{0.060} \\
\hline & Female & 60 & 3.22 & 0.993 & & \\
\hline \multirow{2}{*}{$\begin{array}{l}\text { Instagram is a good platform to } \\
\text { learn new words in English. }\end{array}$} & Male & 60 & 4.15 & 1.039 & \multirow{2}{*}{118} & \multirow{2}{*}{0.294} \\
\hline & Female & 60 & 4.33 & 0.857 & & \\
\hline Instagram is a good platform to & Male & 60 & 2.83 & 1.251 & 113.522 & 0.266 \\
\hline
\end{tabular}


\begin{tabular}{lllllll}
\hline improve & English & grammar & Female & 60 & 3.07 & 1.023
\end{tabular}

knowledge.

$\begin{array}{lllll}\text { Instagram is a good platform to } & \text { Male } & 60 & 3.47 & 0.999\end{array}$

\begin{tabular}{llllll}
\cline { 2 - 5 } improve overall English skills. & Female & 60 & 3.42 & 0.829
\end{tabular}

$\begin{array}{lllll}\text { Instagram is a good platform to } & \text { Male } & 60 & 3.15 & 1.022\end{array}$

reach authentic English

materials.

Female $\quad 60 \quad 2.95 \quad 0.964$

118

0.272

\begin{tabular}{|c|c|c|c|c|c|c|}
\hline Instagram makes learning & Male & 60 & 3.78 & 1.075 & \multirow{2}{*}{109.756} & \multirow{2}{*}{0.340} \\
\hline English more interesting. & Female & 60 & 3.95 & 0.811 & & \\
\hline Instagram makes learning & Male & 60 & 3.33 & 1.068 & \multirow{2}{*}{109.042} & \multirow{2}{*}{0.055} \\
\hline English easier. & Female & 60 & 3.67 & 0.795 & & \\
\hline Instagram increases my & Male & 60 & 3.67 & 1.068 & \multirow[b]{2}{*}{118} & \multirow[b]{2}{*}{0.292} \\
\hline $\begin{array}{l}\text { motivation to communicate } \\
\text { using English. }\end{array}$ & Female & 60 & 3.87 & 0.999 & & \\
\hline Instagram increases my & Male & 60 & 3.60 & 1.045 & \multirow[b]{2}{*}{118} & \multirow[b]{2}{*}{0.459} \\
\hline $\begin{array}{l}\text { motivation to read English } \\
\text { materials. }\end{array}$ & Female & 60 & 3.73 & 0.918 & & \\
\hline \multirow{2}{*}{$\begin{array}{l}\text { Instagram increases my } \\
\text { motivation to write in English. }\end{array}$} & Male & 60 & 3.38 & 1.106 & \multirow{2}{*}{118} & \multirow{2}{*}{0.858} \\
\hline & Female & 60 & 3.42 & 0.926 & & \\
\hline \multirow{2}{*}{$\begin{array}{l}\text { Instagram encourages me to } \\
\text { spend more time learning } \\
\text { Fnolish }\end{array}$} & Male & 60 & 3.30 & 1.094 & \multirow[b]{2}{*}{118} & \multirow[b]{2}{*}{0.586} \\
\hline & Female & 60 & 3.40 & 0.906 & & \\
\hline
\end{tabular}

The data presented in Table 2 indicated that the difference between male and female Saudi learners' attitudes towards the use of Instagram as a language learning tool was not statistically significant in all of the items $(p>0.05)$. Accordingly, this result verifies the validity of the second research hypothesis "There are no significant effects of gender on Saudi EFL learners' attitudes towards the use of Instagram as a language learning tool." The findings of this study as regards gender are consistent with those of Aifan (2015), who indicated that there were no significant differences between Saudi male and female students' attitudes towards the use of social media technologies to support their learning.

\section{Conclusion and Implications}

The purpose of this study was to investigate the overall attitudes of Saudi English language learners towards the use of Instagram as a language learning tool. It also aimed to find out the gender impact on learners' attitudes towards the use of Instagram as a language learning tool. The results revealed from the questionnaire showed that students have mostly positive attitudes towards the use of Instagram as a language learning tool. It was also found that there were no significant differences between male and female leaners in terms of their attitudes towards the use of Instagram as a language learning tool.

The present study raises the possibility that Instagram should be used as a supportive tool in English language teaching and learning. Teachers can use Instagram to provide their students with interactive learning environments to enhance their motivation and performance in or 
outside classrooms. Further, teachers can employ Instagram in the teaching process to provide collaborative and cooperative learning. Also, Instagram can be used as a useful tool for teaching and learning vocabulary. Additionally, teachers can use pictures and videos of Instagram to motivate students to brainstorm new ideas to write descriptive essays. However, teachers should be given courses on the most effective and appropriate use of such social media platforms in language teaching.

However, as with the majority of studies, the design of the current study is subject to limitations. The subjects were limited to Saudi learners at Qassim University. Therefore, it seems difficult to generalize the findings to the entire population of EFL learners in Saudi Arabia. Moreover, further research that might shed light on the same issue should employ interviews or experimental methods to provide a deeper understanding of the dimensions of using Instagram as a language learning tool.

\section{References}

AbuSa'aleek, A. O. (2015). Students' perceptions of English language learning in the Facebook. Teaching English with Technology, 15(4), 60-75.

Aifan, H. A. (2015). Saudi students' attitudes toward using social media to support learning (Publication No. 3713504). Doctoral dissertation. ProQuest Dissertations \& Theses Global.

Akhiar, Y., Mydin, A., \& Adi Kasuma, S. A. (2017). Students' perceptions and attitudes towards the use of Instagram in English language writing. Malaysian Journal of Learning and Instruction (MJLI), Special Issue on Graduate Students Research on Education, 47-72. https://doi.org/10.32890/mjli2017.0.0.7796

AlQahtani, N. A. (2018). The effect of social networks on the improvement of Saudi EFL students. Journal of Humanities and Social Sciences, 2(8), 137-150. https://doi.org/10.26389/AJSRP.N130618

Al-Ali, S. (2014). Embracing the selfie craze: Exploring the possible use of Instagram as a language mLearning tool. Issues and Trends in Educational Technology, 2(2), 1-16. https://doi.org/10.2458/azu_itet_v2i2_ai-ali

Aljaad, N. H. M. (2016). The role of social communication tools in education from the Saudi female students' perceptions. International Education Studies, 9(8), 194-202. https://doi.org/10.5539/ies.v9n8p194

Aloraini, N. (2018). Investigating Instagram as an EFL learning tool. Arab World English Journal, Special issue on CALL, (4), 174-184. https://doi.org /10.24093/awej/call4.13

Alqarni, S., Lally, V., \& Houston, M. (Eds.). (2019). Saudi students' attitude toward using social media technologies as a supportive tool in English language learning. In L. Gómez Chova, A. López Martínez, \& I. Candel Torres (Eds.), EDULEARN19 proceedings: 11th international conference on education and new learning technologies (pp. 10662-10667). Palma, Spain: Iated Digital Library. 
Alsharidi, N. K. M. (2018). The use of Twitter amongst female Saudi EFL learners. International Journal of Applied Linguistics \& English Literature, 7(4), 198-205. https://doi.org/10.7575/aiac.ijalel.v.7n.4p.198

Bal, E., \& Bicen, H. (2017). The purpose of students' social media use and determining their perspectives on education. Procedia Computer Science, 120, 177-181. https://doi-org.sdl.idm.oclc.org/10.1016/j.procs.2017.11.226

Beqiri, G. (2014). The impact of social media on higher education in Kosovo: The student's perspective. Academic Journal of Interdisciplinary Studies, 3(2), 155-163. https://doi.org/10.5901/ajis.2014.v3n2p155

Chartrand, R. (2012). Social networking for language learners: Creating meaningful output with Web 2.0 tools. Knowledge Management \& E-Learning: An International Journal, 4(1), 97-101. https://doi.org/10.34105/j.kmel.2012.04.009

Erarslan, A. (2019). Instagram as an education platform for EFL learners. Turkish Online Journal of Educational Technology - TOJET, 18(3), 54-69.

Gamble, C., \& Wilkins, M. (2014). Student attitudes and perceptions of using Facebook for language learning. Dimension, 3, 49-73. Retrieved from http://files.eric.ed.gov/fulltext/EJ1080264.pdf

Gonulal, T. (2019). The use of Instagram as a mobile-assisted language learning tool. Contemporary Educational Technology, 10(3), 309-323. https://doi.org/10.30935/cet.590108

Handayani, A. D., Cahyono, B. Y., \& Widiati, U. (2018). The Use of Instagram in the Teaching of EFL Writing: Effect on Writing Ability and Students' Perceptions. Studies in English Language Teaching, 6(2), 112. https://doi.org/10.22158/selt.v6n2p112

Harinie, L. T., Sudiro, A., Rahayu, M., \& Fatchan, A. (2017). Study of the Bandura's social cognitive learning theory for the entrepreneurship learning process. Science Publishing Group, 6(1), 1-6. https://doi.org/10.11648/j.ss.20170601.11

Hmelo-Silver, C. E. (2006). Analyzing collaborative learning: Multiple approaches to understanding processes and outcomes. In S. Barab, K. Hay, \& D. Hickey (Eds.), Proceedings of the 7th International Conference on Learning Sciences (pp. 1059-1065). Mahwah, NJ: Lawrence Erlbaum Associates.

Jacobs, G. M., Power, M. A., \& Loh, W. I. (2002). The teacher's sourcebook for cooperative learning: Practical techniques, basic principles, and frequently asked questions. Thousand Oaks: Corwin Press.

Kaya, T., \& Bicen, H. (2016). The effects of social media on students' behaviors; Facebook as a case study. Comput Hum Behav, 59, 374-379. https://doi.org/10.1016/j.chb.2016.02.036

Mompean, J. A., \& Fouz-González, J. (2016). Twitter-based EFL pronunciation instruction. Language Learning \& Technology, 20(1), 166-190.

Razak, N. A., Saeed, M., \& Ahmad, Z. (2013). Adopting social networking Sites (SNSs) as interactive communities among English foreign language (EFL) learners in writing: 
Opportunities and challenges. English Language Teaching, 6(11), 187-198. https://doi.org/10.5539/elt.v6n11p187

Renaldi, S. (2020). Using Instagram to Improve Students' Ability and Interest in Writing Descriptive Paragraph. Journal La Edusci, $\quad 1(1), \quad$ 12-24. https://doi.org/10.37899/journallaedusci.v1i1.28

Sharma, V. (2019). Saudi students' perspective on social media usage to promote EFL learning. International Journal of Linguistics, Literature and Translation, 2(1), 129-139. https://doi.org/10.32996/ijllt.2019.2.1.17

Shazali, S. S., Shamsudin, Z. H., \& Yunus, M. M. (2019). Instagram: A Platform to Develop Student's Writing Ability. International Journal of Academic Research in Business and Social Sciences, 9(1), 88-98. https://doi.org/10.6007/ijarbss/v9-i1/5365

Soviyah, S., \& Etikaningsih, D. R. (2018). Instagram use to enhance ability in writing descriptive texts. Indonesian EFL Journal, $4(2), \quad 32-38$. https://doi.org/10.25134/ieflj.v4i2.1373

Ta'amneh, I. M. (2018). Saudi EFL learners' attitudes towards the effect of the internet and social media in developing their English language. International Journal of Humanities and Social Science, 8(6), 88-96. https://doi.org/10.30845/ijhss.v8n6p10

Taskiran, A., Gumusoglu, E. K., \& Aydin, B. (2018). Fostering foreign language learning with Twitter: Reflections from English learners. Turkish Online Journal of Distance Education, 19(1), 100-116. https://doi.org/10.17718/tojde.382734

Vivakaran, M. V., \& Neelamalar, M. (2018). Utilization of Social Media Platforms for Educational Purposes among the Faculty of Higher Education with Special Reference to Tamil Nadu. Higher Education for the Future, 5(1), 4-19. https://doi.org/10.1177\%2F2347631117738638

Vygotsky, L. S. (1978). Interaction between learning and development. In M. Cole, V. John-Steiner, S. Scribner, \& E. Souberman (Eds.), Mind and society: The development of higher psychological processes (pp. 79-91). Cambridge, MA: Harvard University Press.

Yang, H. L., \& Tang, J. H. (2003). Effects of social network on student performance: A web-based forum study in Taiwan. Journal of Asynchronous Learning Networks, 7(3), 93-107. https://doi.org/10.24059/OLJ.V7I3.1848

\section{Copyrights}

Copyright for this article is retained by the author(s), with first publication rights granted to the journal.

This is an open-access article distributed under the terms and conditions of the Creative Commons Attribution license (http://creativecommons.org/licenses/by/4.0/) 